\title{
The Covid-19 Pandemic Destroys the Economic Conditions of Community Households? (Case in South Kuta-Bali)
}

\author{
I Made Sarmita ${ }^{1}$, Ida Bagus Made Astawa ${ }^{2}$ \\ made.sarmita@undiksha.ac.id, bagus.astawa@undiksha.ac.id \\ ${ }^{1}$ Universitas Pendidikan Ganesha, Indonesia
}

\begin{abstract}
This research was conducted with the aim of knowing the micro-economic conditions of the community of South Kuta before and during the Covid-19 pandemic, both as local community and as migrants. To achieve this aim, the research was conducted using a survey design involving 199 respondents, consisting of 123 local community and 76 migrants obtained by snowball sampling technique. Data analysis was carried out using descriptive and different test techniques (t-test paired sample). The results showed that: before the pandemic, the average income of the community of South Kuta was far above the UMK in Badung Regency in 2020 (average income of migrants > average income of local community). During the pandemic, the average income of the community fell well below the UMK (average income of migrants < average income of local community). In terms of expenditure, both before and during the pandemic, on average, they were still above a decent standard of living (using the UMK reference). However, it is undeniable that public consumption has decreased after the pandemic. This situation is fully followed by local community, not so with migrants whose consumption has decreased during the pandemic to below a decent standard of living in Badung Regency. This description is statistically strengthened, both for income and expenditure based on the status of the community before and during the pandemic. The calculated $t$ value for all indicators and subjects involved is always greater than the $t$ table value and is significant at the 0.00 level. The difference in the $t$ value for income is $15.27>t$ table with a significance level of $5 \%=1,97$, and in expenditure where the value of $\mathrm{t}$ observation $=10.35>\mathrm{t}$ table 1.97 at a significance level of $5 \%$. This significant difference in microeconomic conditions indicates the magnitude of the impact of the Pandemic on the lives of the community in South Kuta.
\end{abstract}

Keywords: Covid-19 Pandemic, Income, Expenditure, Local Communities, Migrants

\section{Introduction}

Until now, the world is facing the Covid-19 Pandemic (Corona Virus Diseases-2019). Corona virus is a virus that infects humans as well as various types of animals, first discovered in 1966 by Tyrell and Bynoe who cultured the virus from patients with the common cold [1]. Covid-19 is structurally related to the virus that causes severe acute respiratory syndrome (SARS). As in the two previous cases of the emergence of coronavirus disease in the last 18 years, namely SARS in 2002 and 2003 and the Middle East Respiratory Syndrome (MERS) in 2012 to date, the Covid-19 outbreak has posed a critical challenge to global public health [2].

The World Health Organization (WHO) since January 2020 has declared the world to be in a global emergency regarding this virus. This is an extraordinary phenomenon that occurs on earth in the 21 st century, the scale of which may be comparable to World War II, because large-scale events are almost entirely postponed or even canceled. This condition has happened only during the world war, there has never been another situation that can cancel 
these events [3]. In Indonesia, the Government has issued a disaster emergency status starting on February 29, 2020 and on April 13, 2020, the President declared Non-Natural Disasters Spreading Corona Virus Disease 2019 (Covid-19) as National Disasters. Various programs and efforts have been carried out by the Government of Indonesia to suppress the spread of this virus. However, the reality is that until the end of January 2021, the cases continued to increase until 1,078,314 people had been exposed, with 873,221 people having recovered and 29,998 people dying [4].

As a disaster, the spread of COVID-19 has an impact on almost all sectors of life. Not only health, the economic sector is also experiencing a serious impact due to the corona virus pandemic. Restrictions on community activities affect business activities which then have an impact on the economy. The report from the Central Statistics Agency (BPS) in August 2020 stated that Indonesia's economic growth in the second quarter of 2020 was minus 5.32 percent. Previously, in the first quarter of 2020, BPS reported that Indonesia's economic growth only grew by 2.97 percent, down far from growth of 5.02 percent in the same period in 2019 . This weakening economic performance also has an impact on the employment situation in Indonesia.

The SMERU Research Institute, an independent institution that conducts public research and studies, in August 2020 released some of its findings. One of the findings is the increasing number of unemployed in Indonesia. The inhibition of economic activity automatically makes business actors perform efficiency to reduce losses, as a result many workers are laid off or even laid off (PHK). Based on data from the Ministry of Manpower as of April 7, 2020, due to the Covid-19 pandemic, there were 39,977 companies in the formal sector that chose to lay off and lay off their workers. A total of 1,010,579 workers were affected by this. In detail, 873,090 workers from 17,224 companies were laid off, while 137,489 workers were laid off from 22,753 companies. Meanwhile, the number of companies and workers affected in the informal sector were 34,453 companies and 189,452 workers. However, this figure does not describe the overall unemployment rate because it does not include unemployment from the informal sector and the new labor force who are still unemployed. The SMERU research team then simulated the calculation of the increase in total unemployment and calculated the amount of reduction in labor absorption from each business sector due to the economic contraction until the end of March 2020. The simulation results show that the TPT (Open Unemployment Rate) increased from 4.99 percent in February 2020 (BPS data) to around 6.17 percent to 6.65 percent in March 2020. This percentage is equivalent to an increase in the number of reductions in labor absorption which reached around 1.6 million to 2.3 million people [5].

Bali as the main destination for tourism in Indonesia and the world has also felt a tremendous impact from this pandemic. Some have even stated that the impact of this pandemic is far more severe than when Bali was bombed in 2002 and 2005, including when Mount Agung erupted in 2017. Bali today is not like Bali in 2019 and before. If in the past Bali was always synonymous with the hustle and bustle of tourism which was non-stop 24 hours, now the situation is $180^{\circ}$ different. The lack of a pulse in the life of tourism in Bali ultimately affected the economic condition of Bali, which was minus 1.14 percent in the first quarter and fell sharply to minus 10.98 percent in the second quarter of 2020. On a micro level, the paralysis of tourism had an impact on the household life of the Balinese people. most of whom depend on this sector for their livelihood.

South Kuta is one of the areas in Bali, precisely in Badung Regency, which can represent the state of Bali which has changed in contrast during this Covid-19 pandemic. This is because this area is a mainstay tourism area for Badung and Bali Regencies which before the pandemic 
contributed greatly to Regional Original Income (PAD). In South Kuta, there are a number of tourist attractions such as Nusa Dua, Tanjung Benoa, Pandawa Beach, Uluwatu, Garuda Wisnu Kencana (GWK), Jimbaran, and so on and in this area, international standard tourism accommodation facilities and infrastructure have been built which are often used as venues for organizing events and world conferences. In Badung Regency, South Kuta is the area with the highest population growth rate compared to other sub-districts at 5\% (Exponential calculation) [6-7], indicates that in-migration has contributed greatly to the population growth [8]. South Kuta is like "sugar" surrounded by "ants", not only by tourists but also by migrants who enjoy the blessings of tourism. This situation describes the heterogeneity of the population. During this pandemic period, just like the situation in Bali and other regions in general, many workers in the tourism sector and other related sectors have their working hours reduced and not a few have to be laid off (PHK). To find out more about the economic situation of the people of South Kuta, both local communities and migrants/migrants, before the pandemic and during the Covid-19 pandemic, this research was conducted. This is important to do to obtain information on a micro scale related to the sustainability of the lives of the people of South Kuta Bali in the midst of the Covid-19 pandemic so that the most feasible alternative economic policies can be drawn up.

\section{Method}

The research design used in this study was a survey, namely a method of collecting information from a number of samples as respondents facilitated by a questionnaire [9].Sampling of the area / location was determined by purposive sampling and individual sampling was determined by the snowball sampling technique. The number of respondents involved through the snowball technique was 199 people. Data analysis was carried out using descriptive analysis techniques. In addition, to strengthen the description that there are differences with the different test technique (t-test), so that statistically it will be possible to know the significance of the existing economic conditions before and during the COVID-19 pandemic, both the status of local communities and migrants

\section{Result and Discussions}

\section{Community Economic Conditions before the Covid-19 Pandemic}

The economic condition of the South Kuta community, both local people and migrants before the pandemic period, was seen from the work they were involved in, income, expenses, and expenditure needs before March 2020. Based on the results of research that has been carried out, data on community work is obtained, where more than half the number of respondents (58\%) who are involved in working in the tourism sector such as hotel workers, restaurants, and the like. As an area that is indeed the center of tourism in South Bali, it is very natural that most of the people work in this sector. Not only local people who enjoy the blessings of tourism, migrant communities also flock to come here and get directly involved in this sector. Before the pandemic, this sector was the backbone of the household economy. The tourism sector is a transformation of the agricultural sector which is increasingly getting out of place, especially in South Kuta[10].

Before the pandemic, the average income of the people of South Kuta is more than half earn above the UMK up to IDR 5,000,000/month. On average, the community's income is Rp. $4,916,583$, which is already above the UMK of Badung Regency in 2020 which is set at Rp. 2,930,092 based on the Decree of the Governor of Bali Number 2193/03-G/HK/2019. This 
average income indicates the economic condition of the people who are already prosperous, far above the minimum wage/minimum standard to be able to live properly in this area. This is certainly very grateful, the blessing of tourism is felt for the community. The dominance of the income range in this interval is contributed by both local community groups and migrant groups. However, the tendency for the income group of the people of South Kuta before the pandemic for the local community was around/close to the UMK, while for the migrant group it was far above the UMK. It is evident from the average income, which shows that the average income of migrants is much higher than the average income of the local community. This is in line with the findings of other researchers[11-14], who found that the work ethic of migrants was higher than the work ethic of the local community, thus allowing for differences in the income earned. Migrants generally have a high work ethic even though they often get unfair treatment [15-18].

The distribution of income obtained is almost the same as the distribution of expenditures for the people of South Kuta. On average, the highest expenditure is in the range above the UMK to IDR 5,000,000 and the trend tends to be towards/close to the UMK figure. This is supported by the two sample groups involved, both local communities and migrant groups. However, the average monthly expenditure is higher for the migrant group than for the local community group, as is the income earned. The cost of living is relatively the same, and other needs such as the cost of renting a house by the migrant group, making the expenditure higher than the local community group. Expenditures made by local community groups are relatively balanced to meet food and non-food needs. Not so with the group of migrants whose spending is mostly used to meet non-food needs which reaches $63 \%$. In general, people with higher incomes tend to spend more on non-food needs, on the other hand, people with low incomes spend more to meet food needs [19-21]. Overall, the average expenditure of the people of South Kuta is lower than their average income and is devoted to non-food consumption $(53 \%)$. This means that there is a residual fund that can be used for other purposes in the future by the community.

\section{Community Economic Conditions during the Covid-19 Pandemic}

The economic condition of the community during the pandemic can be seen from the same indicators as before. The first indicator is the existence of the work involved with the following data:

Table 1. Existence of Community Work during the Covid-19 Pandemic

\begin{tabular}{lcccccccc}
\hline & \multicolumn{9}{c}{$\begin{array}{c}\text { Work Existence } \\
\text { The Main Job }\end{array}$} & \multicolumn{9}{c}{$\begin{array}{c}\text { Reduction } \\
\text { of } \\
\text { Working } \\
\text { Hours }\end{array}$} & \% & $\begin{array}{c}\text { Termination of } \\
\text { Contract/Layoff }\end{array}$ & $\%$ & Amount & $\%$ \\
Tourism Sector & 9 & 7.8 & 55 & 47.4 & 52 & 44.8 & 116 & 100 \\
Transport/Driver & 2 & 33.3 & 2 & 33.3 & 2 & 33.3 & 6 & 100 \\
Trade/Business & 4 & 44.4 & 4 & 44.4 & 1 & 11.1 & 9 & 100 \\
Honorary/Private & 18 & 48.6 & 13 & 35.1 & 6 & 16.2 & 37 & 100 \\
The Other & 10 & 32.3 & 9 & 29.0 & 12 & 38.7 & 31 & 100 \\
Amount & 43 & 21.6 & 83 & 41.7 & 73 & 36.7 & 199 & 100 \\
\hline
\end{tabular}


Table 1 above shows that most of the people of South Kuta during the pandemic experienced a reduction in working hours, followed by termination of contracts/layoffs, and one fifth of respondents whose jobs still exist. Those who experienced the highest reduction in working hours and contract terminations, both in absolute and relative terms, came from those who worked in the tourism sector, while those whose jobs still existed the most came from the private/honorary sector. This is in line with the findings of Lemieux et al [22] which states that those most affected by the covid-19 pandemic are in public-related occupations such as accommodation services and food services. It is undeniable that with the onset of the pandemic, the tourism sector has become the worst affected sector in South Kuta. The various policies implemented, both in Bali and the areas of origin of the tourists, are so strict in order to break the chain of the spread of the corona virus, resulting in the movement of people including tourists being so limited. This makes tourist visits to Bali and South Kuta in particular at its lowest point. The lack of tourist visits has caused almost all hotels, restaurants, and all kinds of supporting tourism activities, their operational activities to slow down, even to traffic jams and bankruptcy. As a result of all this, reducing employees' working hours including termination of employment is a difficult choice for entrepreneurs in the tourism sector to avoid [23]. By reducing working hours, even up to termination of employment, it will certainly have an impact on the economic condition of workers [24].

With certainty the real income of the community after the pandemic has slumped. Most of the community, both local communities and migrants have incomes below the UMK Badung Regency which is still valid. On average, if before the pandemic the income of migrants was much higher than the income of the local community, the reverse condition occurred during this pandemic period, where the income of the local community was actually higher/existed (although they were both worse off). Hotels, restaurants, and various other types of companies in the tourism sector are more likely to retain their employees (although their working hours are reduced) who have a long track record in their place of work and are local community status. The intervention of the traditional village to keep the community working, play's a significant role. Reflecting on this, it can be said that migrants have a fate that is not better than that of the local community [17][18]. The low income earned by migrants and the high cost of living have given rise to the phenomenon of re-migration, namely the return of migrants to their respective regions to work just to survive.

The expenditures made by the people of South Kuta follow the income distribution presented previously. Most of the expenditure is below the UMK, both local communities and migrants. This indicates that people's purchasing power has declined. The expenditure made by the community during this pandemic is much higher than the income they receive. This is of course contrary to the phenomenon before the pandemic, where the average income is higher than the expenditure. If before the pandemic, there were a number of funds that could be saved, during the pandemic the savings were one of the sources used to survive. Funds spent during the pandemic, mainly for the fulfillment of primary needs (in this case food) as many as $70 \%$ of respondents, the reverse condition occurred before the pandemic. With reduced working hours and many layoffs, the source of income is minimal or even minus. Therefore, people become selective in spending by prioritizing their food needs

\section{Differences in Community Economic Conditions}

The description of the economic condition of the community in South Kuta before and during the pandemic, both for local community and migrants in the previous section, is statistically strengthened by the results of the t test. These are presented in table 2 below. 
Table 2. The Differences in Income before and during Covid-19 Pandemic

\begin{tabular}{|c|c|c|c|c|c|c|}
\hline & \multicolumn{2}{|c|}{ Whole } & \multicolumn{2}{|c|}{ Local Community } & \multicolumn{2}{|c|}{ Migrants } \\
\hline & $\begin{array}{c}\text { The } \\
\text { Average } \\
\text { Income } \\
\text { before } \\
\text { Pandemi }\end{array}$ & $\begin{array}{c}\text { The } \\
\text { Average } \\
\text { Income } \\
\text { during } \\
\text { Pandemi }\end{array}$ & $\begin{array}{c}\text { The } \\
\text { Average } \\
\text { Income } \\
\text { before } \\
\text { Pandemi }\end{array}$ & $\begin{array}{c}\text { The } \\
\text { Average } \\
\text { Income } \\
\text { during } \\
\text { Pandemi }\end{array}$ & $\begin{array}{c}\text { The } \\
\text { Average } \\
\text { Income } \\
\text { before } \\
\text { Pandemi }\end{array}$ & $\begin{array}{c}\text { The } \\
\text { Average } \\
\text { Income } \\
\text { during } \\
\text { Pandemi }\end{array}$ \\
\hline Mean & 4916582.91 & 1793718.59 & 4297154.47 & 2026829.27 & 5919078.95 & 1416447.37 \\
\hline $\begin{array}{l}\text { Observations } \\
\text { Pearson }\end{array}$ & 199.00 & 199.00 & 123.00 & 123.00 & 76.00 & 76.00 \\
\hline $\begin{array}{l}\text { Correlation } \\
\text { Hypothesized } \\
\text { Mean }\end{array}$ & 0.75 & & 0.93 & & 0.12 & \\
\hline Difference & 0.00 & & 0.00 & & 0.00 & \\
\hline Df & 198.00 & & 122.00 & & 75.00 & \\
\hline t Stat & 15.27 & & 14.42 & & 10.54 & \\
\hline $\begin{array}{l}\mathrm{P}(\mathrm{T}<=\mathrm{t}) \text { one- } \\
\text { tail } \\
\text { t Critical }\end{array}$ & 0.00 & & 0.00 & & 0.00 & \\
\hline $\begin{array}{l}\text { one-tail } \\
\mathrm{P}(\mathrm{T}<=\mathrm{t}) \text { two- }\end{array}$ & 1.65 & & 1.66 & & 1.67 & \\
\hline $\begin{array}{l}\text { tail } \\
\text { t Critical }\end{array}$ & 0.00 & & 0.00 & & 0.00 & \\
\hline two-tail & 1.97 & & 1.98 & & 1.99 & \\
\hline
\end{tabular}

Table 2 above shows that the observation $\mathrm{t}$ value is $15.27>\mathrm{t}$ table with a significance level of $5 \%=1.97$. This applies to the two groups of people who are respondents, namely local people with an observation $\mathrm{t}$ value $=14.42>\mathrm{t}$ table $=1.98$, and migrants with an observation $t$ value $=10.54>1.99$. In accordance with statistical provisions, this means that there is a significant difference between income before and during the pandemic that the people of South Kuta. This statistical test strengthens the previous descriptive explanation, before the pandemic, people had incomes that were far above the UMK, during the pandemic their incomes fell far below the UMK because most of their working hours were reduced and also experienced layoffs. This is a reality that needs further attention from policy makers.

Other differences in economic indicators can also be seen from the expenditure side as presented in the following table.

Table 3. The Differences in Expenditure before and during Covid-19 Pandemic

\begin{tabular}{|c|c|c|c|c|c|c|}
\hline & \multicolumn{2}{|c|}{ Whole } & \multicolumn{2}{|c|}{ Local Community } & \multicolumn{2}{|c|}{ Migrants } \\
\hline & $\begin{array}{c}\text { The } \\
\text { Average } \\
\text { Expenditure } \\
\text { before } \\
\text { Pandemi }\end{array}$ & $\begin{array}{c}\text { The } \\
\text { Average } \\
\text { Expenditure } \\
\text { during } \\
\text { Pandemi }\end{array}$ & $\begin{array}{c}\text { The } \\
\text { Average } \\
\text { Expenditure } \\
\text { before } \\
\text { Pandemi }\end{array}$ & $\begin{array}{c}\text { The } \\
\text { Average } \\
\text { Expenditure } \\
\text { during } \\
\text { Pandemi }\end{array}$ & $\begin{array}{c}\text { The } \\
\text { Average } \\
\text { Expenditure } \\
\text { before } \\
\text { Pandemi }\end{array}$ & $\begin{array}{c}\text { The } \\
\text { Average } \\
\text { Expenditure } \\
\text { during } \\
\text { Pandemi }\end{array}$ \\
\hline Mean & 4088693.47 & 2907788.94 & 3871951.22 & 2951219.51 & 4439473.68 & 2837500.00 \\
\hline $\begin{array}{l}\text { Observations } \\
\text { Pearson }\end{array}$ & 199.00 & 199.00 & 123.00 & 123.00 & 76.00 & 76.00 \\
\hline $\begin{array}{l}\text { Correlation } \\
\text { Hypothesized }\end{array}$ & 0.88 & & 0.95 & & 0.58 & \\
\hline Mean & 0.00 & & 0.00 & & 0.00 & \\
\hline
\end{tabular}




\begin{tabular}{lrrr}
\hline Difference & & \\
Df & 198.00 & 122.00 & 75.00 \\
t Stat & 10.35 & 8.75 & 6.71 \\
$\begin{array}{l}P(T<=t) \text { one- } \\
\text { tail }\end{array}$ & 0.00 & 0.00 & 0.00 \\
t Critical one- & 1.65 & 1.66 & 1.67 \\
tail & & 0.00 & 0.00 \\
$\begin{array}{l}P(T<=t) \text { two- } \\
\text { tail }\end{array}$ & 0.00 & 1.98 & 1.99 \\
t Critical & 1.97 & & \\
two-tail & &
\end{tabular}

Likewise with income, statistically there is also a significant difference between expenditures before and during the pandemic, where the value of $\mathrm{t}$ observation $=10.35>\mathrm{t}$ table 1.97 at a significance level of 5\%. This is also consistently supported by both local communities with an observation $\mathrm{t}$ value of $8.75>\mathrm{t}$ table 1.98, and migrants with an observation $t$ value of $6.71>1.99$. The difference in spending made by the community reflects the declining purchasing power of the people. The declining income must be balanced with the decreasing expenditure.

\section{Conclusion}

Based on the results of the research that has been described, it can be concluded that the economic conditions of the people of South Kuta have significant differences between before and during the COVID-19 pandemic. The economic indicators used as a reference are household income and expenditure. Before the pandemic hit, the community's income was far above the UMK in Badung Regency, where the income of people with migrant status was much higher than the income of local communities. During this pandemic, people's incomes decreased drastically, far below the UMK and especially felt by the migrant community. From the expenditure side, the condition follows the pattern of income earned. Before and after the pandemic, on average, they were still above a decent standard of living (using the UMK reference). However, it is undeniable that public consumption has decreased after the pandemic. This situation is fully followed by local people, not so with migrants/migrants whose consumption has decreased during the pandemic to below a decent standard of living in Badung Regency. The priority of public spending before the pandemic was for non-food needs, while during the pandemic the priority was for food needs. This situation applies to both local communities and migrants. The situation described here indicates the magnitude of the impact of the Pandemic on the lives of the people of South Kuta. The government must not remain silent, all efforts must be made together to ensure the survival of the people in the midst of the crisis they are facing. Emergency aids, economic stimulus, and various programs that have been implemented by the government are expected to be consistently implemented and especially need further supervision so that the programs being promoted are right on target.

\section{References}

[1] T. P. Velavan and C. G. Meyer, "COVID-19 is an emerging, rapidly evolving situation.," Trop. Med. Int. Heal., vol. 3, no. 25, pp. 278-280, 2020, doi: 10.1111/tmi.13383.

[2] A. S. Fauci, H. C. Lane, and R. R. Redfield, "Covid-19- Navigating the Uncharted," N. 
Engl. J. Med., vol. 13, no. 382, pp. 1268-1269, 2020, doi: 10.1056/NEJMe2002387.

[3] D. R. Buana, "Analisis Perilaku Masyarakat Indonesia dalam Menghadapi Pandemi Virus Corona (Covid-19) dan Kiat Menjaga Kesejahteraan Jiwa," J. Sos. dan Budaya Syar-I, vol. 7, no. 3, pp. 217-226, 2020, doi: https://doi.org/10.15408/sjsbs.v7i3.15082.

[4] Komite Penanganan Covid-19 dan Pemulihan Ekonomi Nasional, "Situasi virus COVID19 di Indonesia," 2021. https://covid19.go.id/.

[5] J. G. Rizal, "Pandemi Covid-19, Apa Saja Dampak pada Sektor Ketenagakerjaan Indonesia?," kompas, 2020.

[6] Badan Pusat Statistik, "Kecamatan Kuta Selatan Dalam Angka,” Badung, 2011.

[7] Badan Pusat Statistik, "Kecamatan Kuta Selatan Dalam Angka," Badung, 2019.

[8] Romdiati, Mobilitas Penduduk Temporer Di Permukiman Kumuh Kota Surabaya: Pengelolaan Dan Konteksnya Terhadap Penataan Lingkungan. Jakarta: LIPI, 2007.

[9] Tukiran and S. Efendi, Metode Penelitian Survei. Jakarta: LP3ES, 2012.

[10] N. M. L. D. UTAMI, M. ANTARA, and I. G. A. O. SURYAWARDANI, "Sektor Unggulan dan Transformasi Ekonomi di Kabupaten Badung," J. Agribisnis dan Agrowisata, vol. 7, no. 2, pp. 286-295, 2018, doi: https://doi.org/10.24843/JAA.2018.v07.i02.p12.

[11] D. G. A. Dhanendra and K. R. Indrawati, "PERBEDAAN MOTIVASI KERJA DAN ETOS KERJA ANTARA KARYAWAN PENDATANG DENGAN KARYAWAN NON PENDATANG YANG BEKERJA PADA HOTEL BINTANG LIMA DI BALI," J. Psikol. Udayana, vol. 5, no. 1, pp. 207-2017, 2018, doi: https://doi.org/10.24843/JPU.2018.v05.i01.

[12] C. Dawson, M. Veliziotis, and B. Hopkins, "Understanding the Perception of the 'Migrant Work Ethic,", Work Employ. Soc., vol. 32, no. 3, 2017, doi: 10.1177/0950017017706306.

[13] B. Hopkins, "Analysing the 'migrant work ethic' - comparing managers' perceptions of local workers and Central and Eastern European migrants in the United Kingdom," Eur. Urban Reg. Stud., vol. 24, no. 4, pp. 442-452, 2017, doi: https://doi.org/10.1177/0969776416678653.

[14] S. S. Saragih and A. Hermawan, "BUDAYA KERJA PETANI PADA MASYARAKAT TRANSMIGRAN DI KECAMATAN BASARANG KABUPATEN KAPUAS KALIMANTAN TENGAH," Adm. - J. ILMU Adm. DAN Manaj., vol. 3, no. 3, pp. 143 $178,2019$.

[15] H. Dean, "The Ethics of Migrant Welfare," Ethics Soc. Welf., vol. 5, no. 1, pp. 18-35, 2011, doi: https://doi.org/10.1080/17496535.2011.546177.

[16] S. M. Goldenberg, K. C. Brouwer, T. R. Jimenez, S. M. Miranda, and M. R. Mindt, "Enhancing the Ethical Conduct of HIV Research with Migrant Sex Workers: Human Rights, Policy, and Social Contextual Influences," PLoS One, vol. 11, no. 5, 2016, doi: https://doi.org/10.1371/journal.pone.0155048.

[17] Q. Gao, "Reconstituting the neoliberal subjectivity of migrants: Christian theo-ethics and migrant workers in Shenzhen, China," J. Ethn. Migr. Stud., vol. 47, no. 12, pp. 27252744, 2020, doi: https://doi.org/10.1080/1369183X.2020.1739374.

[18] E. Consterdine and S. Samuk, "Temporary Migration Programmes: the Cause or Antidote of Migrant Worker Exploitation in UK Agriculture," J. Int. Migr. Integr., vol. 19, pp. 1005-1020, 2018, doi: https://doi.org/10.1007/s12134-018-0577-x.

[19] Z. M. Shariff and G. L. Khor, "Household food insecurity and coping strategies in a poor rural community in Malaysia," Nutr. Res. Pract., vol. 2, no. 1, pp. 26-34, 2008, doi: https://doi.org/10.4162/nrp.2008.2.1.26. 
[20] M. Euler, V. Krishna, S. Schwarze, H. Siregar, and M. Qaim, "Oil Palm Adoption, Household Welfare, and Nutrition Among Smallholder Farmers in Indonesia," World Dev., vol. 93, pp. 219-235, 2017, doi: https://doi.org/10.1016/j.worlddev.2016.12.019.

[21] I. Knößlsdorfer, J. Sellare, and M. Qaim, "Effects of Fairtrade on farm household food security and living standards: Insights from Côte d'Ivoire," Glob. Food Sec., vol. 29, 2021, doi: https://doi.org/10.1016/j.gfs.2021.100535.

[22] T. Lemieux, K. Milligan, T. Schirle, and M. Skuterud, "Initial Impacts of the COVID-19 Pandemic on the Canadian Labour Market," Univ. Toronto Press, vol. 46, no. 1, pp. 5565, 2020, doi: https://doi.org/10.3138/cpp.2020-049.

[23] H.-M. von Gaudecker, R. Holler, L. Janys, B. Siflinger, and C. Zimpelmann, "Labour Supply in the Early Stages of the COVID-19 Pandemic: Empirical Evidence on Hours, Home Office, and Expectations," Bonn, Germany, 13158, 2020.

[24] B. Celik, K. Ozden, and S. Dane, "The Effects of COVID-19 Pandemic Outbreak on the Household Economy," J. Res. Med. Dent. Sci., vol. 8, no. 4, pp. 51-56, 2020, [Online]. Available: 2/publication/343018688_The_Effects_of_COVID19_Pandemic_Outbreak_on_the_Household_Economy/links/5f11cd9992851c1eff18ccc2 /The-Effects-of-COVID-19-Pandemic-Outbreak-on-the-Household-Economy.pdf. 